\title{
Model Pembelajaran REACT (Relating,Experiencing,Applying,Cooperating, Transfering) disertai Media Video Kejadian Fisika Terhadap Keterampilan Proses Sains dan Hasil Belajar Siswa dalam Pembelajaran Fisika di SMA (REACT Learning Model (Relating, Experiencing, Applying, Cooperating, Transfering) to media of physics phenomenon on Process Skills of Science and Student Achievement in Physics Learning at SMA)
}

\author{
Bayu Angga Dwi Cahyono, Sutarto, I Ketut Mahardika \\ Jln. Kalimantan 37, Jember 68121 \\ E-mail: sutarto@fkip.unej.ac.id
}

Pendidikan Fisika, Fakultas Keguruan dan Ilmu Pendidikan, Universitas Jember (UNEJ)

\begin{abstract}
Abstrak
Penelitian ini berfokus pada implementasi model pembelajaran REACT (relating, experiencing, applying, cooperating, transfering) disertai media video kejadian fisika. Tujuan penelitian ini adalah untuk mengkaji pengaruh model terhadap keterampilan proses sains dan hasil belajar fisika siswa. Penelitian ini dilakukan di SMA Negeri 1 Pakusari. Jenis penelitian ini adalah eksperimen dengan desain post-test only control design. Populasi dalam penelitian ini adalah siswa kelas XI MIPA di SMA Negeri 1 Pakusari semester ganjil tahun ajaran 2017/2018. Sampel diperoleh melalui cluster random sampling, XI MIPA 4 terpilih sebagai kelas eksperimen dan XI MIPA 3 terpilih sebagai kelas kontrol. Teknik pengumpulan data adalah tes, observasi, wawancara dan dokumentasi. Teknik analisis data menggunakan Independent Samples T-Test. Hasil penelitian menunjukkan bahwa model pembelajaran REACT (relating, experiencing, applying, cooperating, transfering) disertai video kejadian fisika berpengaruh signifikan terhadap hasil belajar siswa dalam pembelajaran fisika di SMA Negeri 1 Pakusari dan model pembelajaran REACT (relating, experiencing, applying, cooperating, transfering) disertai video kejadian fisika berpengaruh signifikan terhadap keterampilan proses sains siswa dalam pembelajaran fisika di SMA Negeri 1 Pakusari. Jadi dapat disimpulkan bahwa model pembelajaran REACT (relating, experiencing, applying, cooperating, transfering) disertai media video kejadian fisika berpengaruh secara signifikan terhadap keterampilan proses sains dan hasil belajar fisika siswa di SMA Negeri Pakusari.
\end{abstract}

Kata Kunci : model pembelajaran REACT, video kejadian fisika, keterampilan proses sains, hasil belajar.

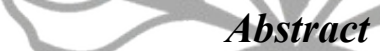

This research focused on implementation of REACT learning model (relating, experiencing, applying, cooperating, transfering) to media of physics phenomenon. The purpose of this study was examine the effect of the model on the skills of the science process and the students' physics learning achievement. This research was conducted on SMA Negeri 1 Pakusari. This type of research was experiment with post-test design only control design. Population in this research was student of class XI MIPA in SMA Negeri 1 Pakusari odd semester of academic year 2017/2018. Samples were obtained through cluster random sampling, XI MIPA 4 was selected as experimental class and XI MIPA 3 as control class. Data collection techniques are tests, observations, interviews and documentation. Data analysis technique used Independent Samples T-Test. The results showed that the learning model REACT (relating, experiencing, applying, cooperating, transfering) to media of physics phenomenon significantly on students' physics learning achievement at SMA Negeri 1 Pakusari and REACT learning model (relating, experiencing, applying, cooperating, transfering ) to media of physics phenomenon have a significant effect to the students' science process skill in physics learning at SMA Negeri 1 Pakusari. So it can be concluded that the REACT learning model (relating, experiencing, applying, cooperating, transfering) to media of physics phenomenon significantly on the skills of science process and students' physics learning achievement at SMA Negeri 1 Pakusari.

Keywords : REACT learning model, physical event video, science process skills, student achievement

\section{Pendahuluan}

Fisika merupakan salah satu cabang dari Ilmu Pengetahuan Alam (IPA) atau sains. Sains berkaitan dengan cara mencari tahu tentang alam secara sistematis, berupa penemuan, penguasaan, kumpulan pengetahuan, yang berupa fakta-fakta, konsep-konsep, atau prinsip-prinsip, serta proses pengembangan lebih lanjut dalam menerapkan pengetauan di dalam kehidupan sehari-hari [1]. Menurut Bloom kemampuan pemahaman kemampuan konsep adalah hal penting dalam kemampuan intelektual yang selalu ditekankan di sekolah dan Perguruan Tinggi [2]. Hal ini menunjukkan bahwa pembelajaran fisika bukanlah pembelajaran hafalan tetapi lebih menuntut ke pemahaman konsep bahkan aplikasi konsep [2]. Pembelajaran fisika 
hendaknya mematuhi kaidah proses dan produk [3]. Proses yang dimaksud adalah proses ilmiah, yaitu proses yang langkah-langkahnya menggunakan prosedur atau metode ilmiah. Adapun produk fisika yang dimaksud adalah pengetahuan yang dapat berupa fakta, konsep, prinsip, prosedur, teori atau hukum. Melalui pembelajaran fisika yang baik dan benar, diharapkan siswa tidak hanya paham mengenai produk fisika saja namun siswa juga paham mengenai proses untuk mendapatkan produk tersebut seperti yang dilakukan oleh para fisikawan.

Berdasarkan hasil observasi dan wawancara terbatas yang telah dilakukan di beberapa sekolah di SMA di Kabupaten Jember. Peneliti memperoleh informasi bahwa dalam pembelajaran fisika guru biasanya menggunakan model pembelajaran kooperatif dengan membagi siswa kedalam beberapa kelempok kemudian guru menjelaskan dengan metode ceramah. Pembelajaran seperti itu masih berpusat pada guru (Teacher Center) dan terkesan sebagai proses transfer pengetahuan dari pikiran guru ke dalam pikiran siswa [4]. Oleh karena itu siswa kurang berperan aktif dalam membangun dan menemukan sendiri pengetahuannya sehingga hasil belajar fisika siswa menjadi rendah.

Bedasarkan hasil observasi di sekolah, guru jarang menggunakan kegiatan eksperimen dalam pembelajaran sehingga keterampilan proses sains menjadi siswa rendah. Pembelajaran seperti ini kurang melibatkan siswa, sehingga siswa berperan pasif dalam pembelajaran. Oleh sebab itu pembelajaran fisika seharusnya mampu memberdayakan siswa, artinya pembelajaran mampu mendorong siswa untuk mengkonstruksi pengetahuan di benak mereka sendiri dan mampu menerapkan pengetahuan tersebut untuk memecahkan masalah dalam kehidupan sehari-hari [5].

Hasil belajar dan kemampuan proses sains dapat diperbaiki dengan melaksanakan pembelajaran berbasis kontekstual. Pembelajaran kontekstual adalah proses pembelajaran yang melibatkan siswa dalam aktivitas penting yang membantu mereka mengaitkan pelajaran akademis dengan konteks kehidupan nyata yang mereka hadapi [6]. Hakikat pembelajaran konstektual (Contextual Teaching and Learning) merupakan konsep belajar yang membantu guru mengaitkan materi antara yang diajarkan dengan dunia nyata [7]. Salah satu pengembangan pembelajaran kontekstual adalah model pembelajaran REACT. Model pembelajaran $R E A C T$ terdiri dari lima tahapan yaitu relating (mengaitkan), experiencing (mengalami), applying (menerapkan), cooperating (kerjasama), dan transferring (memindahkan). Model pembelajaran ini tidak hanya mengajarkan tentang konsep dan fakta saja namun mengarahkan siswa menemukan makna dalam pembelajaran melalui kegiatan pengaitan konsep materi dengan kehidupan sehari-hari.

Model pembelajaran REACT memiliki kekurangan yaitu siswa lemah dalam memberikan contoh aplikasi materi dalam kehipupan sehari-hari [8]. Oleh karena itu, model pembelajaran REACT akan dipadukan dengan media audiovisual. Media audiovisual merupakan gabungan media visual (gambar) dan media audio (suara). Media audiovisual berpeelajaranran dalam menyajikan fenomena-fenomena alam. Penggunaan media audiovisual dapat mengatasi kelemahan model pembelajaran REACT terutama dalam contoh dikehidupan sehari-hari. Dimana siswa dapat melakukan observasi pada media audiovisual. Selain itu perpaduan model pembelajaran REACT dengan media audiovisual diharapkan dapat lebih bermakna dan dapat meningkatkan suasana pembelajaran menjadi menyenangkan.

Berdasarkan uraian tersebut, penelitian ini membahas tentang pengaruh model pembelajaran REACT (relating, experiencing, applying, cooperating, transfering) disertai video kejadian fisika terhadap keterampilan proses sains siswa dalam pembelajaran fisika di SMA serta pengaruh model pembelajaran REACT (relating, experiencing, applying, cooperating, transfering) disertai video kejadian fisika terhadap hasil belajar siswa dalam pembelajaran fisika di SMA.

\section{Metode Penelitian}

Jenis penelitian ini adalah penelitian eksperimen yang dilaksanakan di SMA Negeri 1 Pakusari pada kelas XI MIPA semester ganjil tahun ajaran 2017/2018. Sampel penelitian ditentukan setelah dilakukan uji homogenitas menggunakan uji One-Way ANOVA pada program SPSS 22. Data yang digunakan adalah data nilai ulangan harian pada baba sebelumnya kelas XI MIPA. Berdasarkan hasil uji homogenitas menunjukkan bahwa data dari populasi yang diambil adalah homogen. Langkah selanjutnya penentuan sampel menggunakan teknik cluster random sampling. Teknik cluster random sampling merupakan teknik penentuan sampel dengan bila yang akan diteliti atau suber data sangat luas dengan syarat sampel homogen [9]. Hasilnya kelas XI MIPA 4 sebagai kelas eksperimen yang menggunakan model REACT disertai media video kejadian fisika dan kelas XI MIPA 3 sebagai kelas kontrol yang menggunakan model pembelajaran yang biasa digunakan di sekolah.

Desain penelitian eksperimen ini menggunakan post test only control group design. Desain penelitian post test only control design dapat dilihat pada Gambar 1.

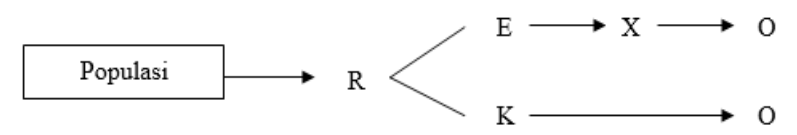

Gambar 1. Desain penelitian postest-only control design

Metode pengumpulan data dalam penelitian ini antara lain menggunakan: observasi, test, dokumentasi dan wawancara. Data hasil keterampilan proses sains kelas eksperimen diperoleh melalui observasi yang dilakukan oleh observer selama proses pembelajaran berlangsung dan dokumentasi dari lembar diskusi dan lembar percobaan. Indikator keterampilan proses sains yang dinilai di kelas eksperimen dengan lembar observasi meliputi melakukan eksperimen, mengamati, mengukur, dan mengkomunikasikan, sedangkan dengan lembar dokumentasi meliputi menyusun hipotesis, mengenali variabel, mengidentifikasi variabel, mengumpulkan dan mengolah data, membuat grafik, dan menarik kesimpulan. Pengambilan data KPS dilakukan 
sebanyak 3 kali yaitu tiap satu kali RPP. Kemudian tiap indikator diambil rata-ratanya untuk dianalisis. Pengumpulan data keterampilan proses sains dilakukan selama proses pembelajaran menggunakan lembar observasi dan dokumentasi dari lembar percobaan dan lembar diskusi selama pembelajaran. Nilai keterampilan proses sains siswa diketahui dari persentase ketercapaian keterampilan proses sains siswa dengan persamaan sebagai berikut:[10].

$$
\text { KPS }=\frac{n}{N} \times 100 \%
$$

Keterangan:

KPS : Keterampilan proses sains siswa

$\mathrm{n}$ : Total skor yang diperoleh siswa

$\mathrm{N}$ : Total skor maksimum

Hasil persentase keterampilan proses sains siswa yang didapatkan dengan menggunakan persamaan tersebut kemudian dicocokkan dengan kriteria keterampilan proses sains siswa yang disajikan pada Tabel 1.[11].

Tabel 1. Kriteria Keterampilan Proses Sains

\begin{tabular}{|c|c|}
\hline Keterampilan Proses Sains (\%) & Kriteria \\
\hline $76 \geq$ Skor $=100$ & Baik \\
\hline $56 \geq$ Skor $=100$ & Cukup Baik \\
\hline $40 \geq$ Skor $=100$ & Kurang Baik \\
\hline Skor $<40$ & Tidak Baik \\
\hline
\end{tabular}

Data hasil belajar diperoleh dari nilai rata-rata post test kelas eksperimen dan kelas kontrol di akhir pembelajaran sebagai nilai kognitif, sedangkan nilai psikomotor diperoleh dari nilai rata-rata keterampialn proses sains, dan nilai afektif diperoleh dari observasi pada saat pembelajaran. Materi yang diajarkan dalam penelitian ini adalah elastisitas zat padat dan hukum hooke. Indikator pada aspek kognitif dibuat sesuai dengan taksonomi Bloom. Indikator yang dipakai mulai $\mathrm{C} 1$ sampai $\mathrm{C} 6$. Soal post test terdiri dari 10 soal uraian (essay).

Teknik analisis data untuk keterampilan proses sains siswa menggunakan Independent Sample T-Test dengan bantuan SPSS 22 untuk mengkaji pengaruh model pembelajaran REACT (relating, experiencing, applying, cooperating, transfering) disertai video kejadian fisika terhadap keterampilan proses sains siswa dalam pembelajaran fisika di SMA Negeri 1 Pakusari dan mengkaji pengaruh model pembelajaran REACT (relating, experiencing, applying, cooperating, transfering) disertai video kejadian fisika terhadap hasil belajar siswa dalam pembelajaran fisika di SMA Negeri 1 Pakusari.

\section{Hasil Penelitian}

Data keterampilan proses sains diperoleh dari observasi yang dilakukan oleh observer dan dokumentasi melalui penilaian lembar percobaan dan lembar diskusi siswa selama proses pembelajaran. Rekapitulasi nilai ratarata keterampilan proses sains kelas eksperimen dan kontrol dapat dilihat pada Tabel 2.

Tabel 2. Nilai rata-rata KPS

\begin{tabular}{|l|c|c|}
\hline \multirow{2}{*}{\multicolumn{1}{|c|}{ Indikator KPS }} & \multicolumn{2}{c|}{ Skor yang Diperoleh (\%) } \\
\cline { 2 - 3 } & Eksperimen & Kontrol \\
\hline Menyusun hipotesis & 75 & 52 \\
\hline Eksperimen & 81 & 75 \\
\hline Mengamati & 87 & 72 \\
\hline Mengukur & 82 & 79 \\
\hline Mengidentifikasi variabel & 89 & 83 \\
\hline $\begin{array}{l}\text { Mengumpulkan dan } \\
\text { mengolah data }\end{array}$ & 79 & 65 \\
\hline Membuat grafik & 69 & 65 \\
\hline Menarik kesimpulan & 66 & 50 \\
\hline Mengkomunikasikan & 65 & 63 \\
\hline Rata-rata KPS & $\mathbf{7 7}$ & $\mathbf{6 7}$ \\
\hline
\end{tabular}

Data hasil belajar diperoleh dari rata-rata nilai post test yang dilakukan setelah proses pembelajaran fisika pada materi elastisitas zat padat dan hukum hook, penilaian lembar observasi dan lembar dokumentasi, serta penilaian lembar sikap selama proses pembelajaran. Post test dilakukan pada kelas eksperimen dan kelas kontrol. Data nilai rata-rata hasil belajar kelas eksperimen dan kelas kontrol dapat dilihat pada Tabel 1 .

\begin{tabular}{|c|c|c|}
\hline \multicolumn{1}{|c|}{ Tabel 3. Rata-rata Hasil Belajar } \\
\hline $\begin{array}{c}\text { Ranah Hasil } \\
\text { Belajar }\end{array}$ & Kelas Kontrol & $\begin{array}{c}\text { Kelas } \\
\text { Eksperimen }\end{array}$ \\
\hline Afektif & 85,34 & 85,48 \\
\hline Psikomotor & 77 & 68 \\
\hline Kognitif & 71,62 & 47,66 \\
\hline Rata-rata & $\mathbf{7 8 , 0 1}$ & $\mathbf{6 7 , 0 6}$ \\
\hline
\end{tabular}

\section{$\checkmark$ Pembahasan}

- Keterampilan proses sains merupakan keterampilan dalam pembelajaran yang terfokus pada aktivitas dan kreativitas siswa untuk mengembangkan kemampuan fisik dan mentalnya. Berdasarkan Tabel 2 indikator tertinggi kelas eksperimen adalah indikator mengidentifikasi variabel dengan rata-rata sebesar 89 . Hal ini dikarenakan pada saat melakukan ekperimen (hand-on activity) siswa membangun pengetahuannya. Ketika melakukan eksperimen siswa mengaitkan pengetahuan yang dipelajari dengan pengetahuan yang dimiliki siswa. Sebagian besar siswa tiap kelompok aktif ketika melakukan eksperimen. Hal ini sejalan dengan yang dikemukakan Fakhruriza bahwa alasan model pembelajaran REACT dapat digunakan dalam pembelajaran salah satunya yaitu siswa lebih aktif karena dalam proses belajar mengajar mereka tidak hanya mendengarkan materi dari guru tetapi juga ikut berperan aktif dalam proses pembelajaran [12]. Selain itu, media video kejadian fisika juga berperan aktif dalam pembelajaran. Hal ini senada dengan yang dikemukakan Ervina bahwa aktivitas pembelajaran dengan menggunakan media video lebih aktif [13]. Sedangkan Indikator terendah 
kelas eksperimen adalah indikator mengkomunikasikan dengan rata-rata sebesar 65. Ketika mengkomunikasikan hasil percobaan tidak semua siswa aktif dalam menyampaikan pendapatnya. Siswa yang tergolong aktif di kelas akan semakin aktif menyampaikan pendapat dan sanggahannya, tetapi siswa yang cenderung pasif akan mewakilkan pendapatnya ke teman sekelompoknya. Siswa cenderung kurang percaya diri ketika harus menyampaikan pendapatnya. Hal ini sesuai dengan hasil penelitian Marnita bahwa peserta didik belum punya rasa percaya diri untuk tampil di depan kelas dan mempresentasikan hasil temuannya [14]. Selain itu, adanya keterbatasan waktu sehingga kesempatan siswa untuk mempresentasikan juga terbatas.

Pada kelas kontrol rata-rata nilai indikator yang tertinggi adalah aspek mengidentifikasi variabel dengan ratarata 83. Hal ini dikarenakan siswa sudah terbiasa menuliskan variabel yang diketahui dan yang ditanyakan dalam mengerjakan soal. Sedangkan rata-rata nilai indikator yang terendah adalah aspek menarik kesimpulan dengan rata-rata 50. Siswa belum terbiasa membuat kesimpulan dalam eksperimen.

Rata-rata nilai keterampilan proses sains kelas eksperimen secara keseluruhan yaitu sebesar 77 dan kelas kontrol sebesar 67. Dari data tersebut tampak bahwa ratarata nilai keterampilan proses sains kelas eksperimen lebih tinggi daripada kelas kontrol. Langkah-langkah dalam model pembelajaran REACT disertai video kejadian fisika melibatkan siswa untuk berperan aktif dalam proses pembelajaran, sehingga dapat membantu melatih dan mengembangkan keterampilan proses sains siswa. Hal ini sejalan dengan penelitian yang dilakukan oleh Selamet yang menyatakan bahwa model pembelajaran REACT dapat meningkatkan pemahaman konsep dan keterampilan proses sains siswa1 tailed) $=0.000$ [8]. Sehingga $0.000 \leq 0,05$, maka hipotesis nihil (Ho) ditolak dan hipotesis alternatif (Ha) diterima. Dengan demikian, dapat dikatakan bahwa model pembelajaran REACT (relating, experiencing, applying, cooperating, transfering) disertai video kejadian fisika berpengaruh signifikan terhadap keterampilan proses sains siswa dalam pembelajaran fisika di SMA Negeri 1 Pakusari.

Hasil belajar merupakan prestasi belajar yang dicapai siswa dalam proses kegiatan belajar mengajar dengan membawa suatu perubahan dan pembentukan tingkah laku seseorang. Nilai rata-rata hasil belajar siswa kemudian diuji menggunakan Independent Sample T Test dengan bantuan SPSS 22. Diperoleh nilai Sig. 0,135 pada Levene's Test for Equality of Variances menunjukkan data homogen. Berdasarkan lajur Equal variances assumed tampak bahwa nilai sig. $(2$ tailed $)=0.000$ maka nilai Sig. $(1$ tailed $)=0.000$. Sehingga $0.000 \leq 0,05$, maka hipotesis nihil (Ho) ditolak dan hipotesis alternatif (Ha) diterima. Dengan demikian dapat dikatakan bahwa model pembelajaran REACT (relating, experiencing, applying, cooperating, transfering) disertai media video kejadian fisika terhadap hasil belajar siswa berpengaruh signifikan terhadap hasil belajar siswa dalam pembelajaran fisika di SMA Negeri 1 Pakusari. Faktor yang mempengaruhi hasil belajar siswa salah satunya adalah model pembelajaran yang digunakan guru [15].
Model pembelajaran REACT disertai media video kejadian fisika dapat menggali pemahaman siswa melalui lima langkah utamanya yaitu relating (mengaitkan), experiencing (eksperimen), applying (penerapan), cooperating (kerjasama) dan transfering (mentranfer). Siswa dibimbing untuk mengaitkan materi yang akan dipelajari dengan yang telah diketahui siswa, melakukan eksperimen, penerapan dengan memberikan contoh dalam kehidupan sehari-hari, kerjasama untuk memecahkan masalah dan transfer pengetahuan dengan menerapkan pemecahan dalam konteks yang baru. Hal ini akan membuat pengetahuan siswa lebih lama untuk diingat dan lebih paham dengan konsepnya. Hasil penelitian ini sejalan dengan penelitian yang dilakukan oleh Riyanto strategi pembelajaran REACT meningkatkan hasil belajar siswa [16]. Penelitian lain juga dilakukan oleh Muzdalifa yang menyatakan bahwa strategi pembelajaran REACT dapat meningkatkan hasil belajar siswa [17]. Senada juga dengan hal tersebut, Ismaya terdapat perbedaan hasil belajar yang signifikan pada siswa yang diajar menggukan model pembelajaran REACT dengan tidak [18].

\section{N. Kesimpulan dan Saran}

Dari hasil penelitian dan pembahasan yang telah diuraikan maka diperoleh kesimpulan sebagai berikut: (1) model pembelajaran REACT (relating, experiencing, applying, cooperating, transfering) disertai video kejadian fisika berpengaruh signifikan terhadap hasil belajar siswa dalam pembelajaran fisika di SMA Negeri 1 Pakusari, dan (2) model pembelajaran REACT (relating, experiencing, applying, cooperating, transfering) disertai video kejadian fisika berpengaruh signifikan terhadap keterampilan proses sains siswa dalam pembelajaran fisika di SMA Negeri 1 Pakusari.

Adapun saran dalam penelitian ini antara lain: (1) bagi guru, dalam menerapkan model pembelajaran REACT (relating, experiencing, applying, cooperating, transfering) disertai video kejadian fisika diperlukan pengaturan waktu yang tepat agar kegiatan pembelajaran berjalan dengan baik., (2) hendaknya guru membimbing siswa selama proses pembelajaran agar kegiatan siswa bisa terarah bagi peneliti lain, dan (3) hasil penelitian ini dapat dijadikan referensi dan landasan untuk melakukan penelitian selanjutnya.

\section{Ucapan Terima Kasih}

Penulis mengucapkan terima kasih kepada dosen pembimbing tugas akhir, serta keluarga besar SMA Negeri 1 Pakusari yang telah membantu dalam menyelesaikan penelitian ini.

\section{Daftar Pustaka}

[1] Depdiknas. 2003. Sistem Pendidikan Nasional. Jakarta: Depdiknas.

[2] Sugiharti. 2005. Penerapan Multiple Intellegences dalam Pembelajaran Fisika. Jurnal Pendidikan Penabur. Vol 4 (5): 29-42.

[3] Indrawati. 2011. Model-model Pembelajaran Implementasinya dalam Pembelajaran Fisika. Jember: Tidak diterbitkan.

[4] Sariningrum, Maghviroh Indry, I Ketut Mahardika, dan Bambang Supriadi. 2017. Pembelajaran Kooperatif Tipe TTW (Think Talk Write) disertai Lks Berbasis Multirepresentasi dalam Pembelajaran Fisika di SMA. Jurnal Pendidikan Fisika (JPF). Vol 5 (4): 378-383. 
[5] Kurniawan, Iwan, I. Made Tegeh, dan I Kadek Suartama. 2014. Pengaruh Strategi Kontekstual REACT Terhadap Kinerja Pemecahan Masalah IPA Siswa SMP Negeri 6 Singaraja. E-Journal Edutech Universitas Pendidikan Ganesha. Vol 2 (1): 1-10.

[6] Muhlisin, Ahmad. 2012. Pengembangan Perangkat Pembelajaran IPA Terpadu Berbasis Contextual Teaching And Learning (CTL) dengan Model Pembelajaran Kooperatif Tipe Student Teams Achievement Division (STAD) Tema Polusi Udara. Journal of Educational Research and Evaluation. Vol 1 (2): 139-145.

[7] Aqib, Zainal. 2015. Model-model, Media dan Strategi pembelajaran Kontekstual (Inovatif). Bandung: YRAMA WIDYA.

[8] Selamet, K., I. W. Sadia, dan K. Suma. 2013. Pengaruh Model Pembelajaran Kontekstual REACT Terhadap Pemahaman Konsep Fisika Dan Keterampilan Proses Sains Siswa Kelas VIII SMP. EJournal Edutech Universitas Pendidikan Ganesha Progam Studi IPA. Vol 3 (1): 1-12.

[9] Sugiyono. 2014. Metode Penelitian Pendidikan. Bandung: Alfabeta.

[10] Wijayanti, P. I., Mosik, dan H. Hindarto. 2010. Eksplorasi Kesulitan Belajar Siswa Pada Pokok Bahasan Cahaya Dan Upaya Peningkatan Hasil Belajar Melalui Pembelajaran Inkuiri Terbimbing. Jurnal Pendidikan Fisika. Vol 6 (1): 1-5.

[11] Widayanto. 2009. Pengembangan Keterampilan Proses dan Pemahaman Siswa Kelas X melalui KIT Optik. Jurnal Pendidikan Fisika Indonesia. Vol 5 (1): 1-7.

[12] Fakhruriza, Okta dan Ika Kartika. 2014. Keefektifan Model Pembelajaran Relating, Experiencing, Applying,Cooperating, Transferring (REACT) untuk Meningkatkan Hasil Belajar Siswa SMP pada Materi Kalor. Jurnal Riset dan Kajian Pendidikan Fisika. Vol 2 (2): 54-57.

[13] Ervina, Fimatu Rizka., Sutarto, dan Indrawati. 2016. Model Pembelajaran Instruction, Doing, dan Evaluating (MPIDE) disertai Resume dan Video Fenomena Alam dalam Pembelajaran Fisika di SMA. Jurnal Pendidikan Fisika. Vol 5 (1). 53-59.

[14] Marnita. 2013. Peningkatan Keterampilan Proses Sains/Melalui Pembelajaran Kontekstual pada Mahasiswa Semester/I Materi Dinamika. Jurnal Pendidikan Fisika Indonesia. ISSN 1693-1246. Vol 9 (1): 43-52.

[15] Slameto. 2010. Belajar dan Faktor yang mempengaruhinya. Jakarta: Rineka Cipta.

[16] Riyanto, Anton Iful, dan Supari Muslim. 2014. Penerapan Srategi Pembelajaran REACT untuk Meningkatkan Hasil Belajar Siswa. Jurnal Pendidikan Teknik Elektro. Vol 3 (2): 37-46.

[17] Muzdalifa, Nina. 2013. Penerapan Pendekatan Kontekstual Berbasis REACT Untuk Meningkatkan Hasil Belajar Fisika Pada Siswa Kelas X SMA Negeri 8 Palu. Jurnal Pendidikan Fisika Tadulako (TPFT) Vol 1 (2): 55-60.

[18] Ismaya, Siva Nur, Subiki, dan Alex Harijanto. 2015. Penerapan Model Pembelajaran Relating, Experiencing, Applying, Cooperating, and Transferring (REACT) terhadap Motivasi dan Hasil Belajar dalam Pembelajaran Fisika di SMA. Jurnal Pendidikan Fisika. Vol 4 (2): 121-127. 